\title{
Is the Trump phenomenon a Symptom or a cause for shifts in U.S. foreign policy?
}

Citation for published version (APA):

Haar, R. (2020). Is the Trump phenomenon a Symptom or a cause for shifts in U.S. foreign policy? Maastricht University. https://doi.org/10.26481/spe.20200130rh

Document status and date:

Published: 30/01/2020

DOI:

10.26481/spe.20200130rh

Document Version:

Publisher's PDF, also known as Version of record

\section{Please check the document version of this publication:}

- A submitted manuscript is the version of the article upon submission and before peer-review. There can be important differences between the submitted version and the official published version of record.

People interested in the research are advised to contact the author for the final version of the publication, or visit the DOI to the publisher's website.

- The final author version and the galley proof are versions of the publication after peer review.

- The final published version features the final layout of the paper including the volume, issue and page numbers.

Link to publication

\footnotetext{
General rights rights.

- You may freely distribute the URL identifying the publication in the public portal. please follow below link for the End User Agreement:

www.umlib.nl/taverne-license

Take down policy

If you believe that this document breaches copyright please contact us at:

repository@maastrichtuniversity.nl

providing details and we will investigate your claim.
}

Copyright and moral rights for the publications made accessible in the public portal are retained by the authors and/or other copyright owners and it is a condition of accessing publications that users recognise and abide by the legal requirements associated with these

- Users may download and print one copy of any publication from the public portal for the purpose of private study or research.

- You may not further distribute the material or use it for any profit-making activity or commercial gain

If the publication is distributed under the terms of Article $25 \mathrm{fa}$ of the Dutch Copyright Act, indicated by the "Taverne" license above, 
Prof. Dr. Roberta Haar

Faculty of Science and Engineering

\section{Is the Trump phenomenon a Symptom or a cause for shifts in U.S. foreign policy?}




\section{Is the Trump Phenomenon a Symptom or the Cause for shifts in US foreign policy? Inaugural Lecture \\ Professor Roberta N. Haar \\ 30 January 2020}

Thank you Madame Rector, Rhianne, Dear Deans, Professors, Doctors; Dear fellow members of the University College Network in The Netherlands (Dear UCANN members); Dear UCM colleagues; Dear Alumni; Dear students; lieve buren; and finally Dear family and friends who came from the United States and the United Kingdom, thank you for coming and thank you for your continued interest in learning more about a controversial topic-one might even call it an overexposed topic for which many in Europe are simply tuning out, not wanting to hear anything more about Trump. So, thank you for being here. I hope that this afternoon that I will not only hold your interest but also even teach you a little something about American politics, American foreign policy and current transatlantic relations.

First, let us have a consideration of the title of my inaugural lecture: Is the Trump Phenomenon a Symptom or the Cause for shifts in U.S. foreign policy? And, in that title, let us reflect upon the latter part, what do I mean by shifts? In other words, I want to start with analyzing the outcome, the policy output in political science terms, before I consider the causes and whether Trump is a cause or not.

\section{Declining Support for International Organizations}

The first shift that I want to point out is that the U.S. is retreating from its global leadership role and its support of the international system that it put in place after the Second World War. Add to this retreat that U.S. foreign policy has become generally more circumspect. Already under President Barack Obama, but certainly under Trump's America First approach to the world, U.S. foreign policy is focusing on specific challenges confronting the U.S. and the opportunities open to it to meet those challenges, rather than expounding long-term commitments or a particular grand strategy.

However, Trump's transactional foreign policy, which often appears to be driven by a potential for personal gain, points to a zero-sum view of the world, which he thinks plays out primarily in economic competition. Trump's worldview distinctly does not support the global system or America's traditional role.

Of course, the decline of the postwar system has been in evidence for some time and Trump is only one factor in a world where Western values and institutions are being challenged by rogue and rising powers. In fact, one could argue that Trump is symptomatic of a larger revision in thinking about the role of global institutions. A paradigm shift that would include the United Kingdom's decision to leave the European Union (which will happen tomorrow). Therefore, does the loss of faith in international organizations, like the EU, reflect broader popular sentiments that they are too distant, too intrusive and ultimately too ineffective? If so, what are American and European leaders meant to do to offset this trend? Moreover, since the same leaders are failing to adequately grapple with rising nationalism, populism and 
Euroscepticism at the national level, why should we think they are able to address the loss of faith in institutions at the global level. I cannot answer all of these questions in my lecture today, but they are important questions nonetheless. Perhaps for others to grapple in future inaugural gatherings.

When I sent out invitations to this lecture, a friend sent me a note about a quote of the great German intellectual and statesman Johann Wolfgang von Goethe, who said: "The thinker makes a great mistake when he [we could add she] asks after cause and effect. They both together make up the indivisible phenomenon." I heartily agree, I do think that Trump is symptomatic of a larger revision in thinking about the role of global institutions. Indeed, as I already noted, America's role in the world has been shifting for some time and analyzing American decline is itself a whole genre of scholarship. However, Trump's residency in the White House is unmistakably hastening U.S. withdrawal or a distancing from a number of international organizations, including NATO. The result is that Trumpian foreign policy is accelerating the overall decline in the relevance of international organizations and the foundations of the international order.

\section{The Escalation of the Burden Sharing Debate}

The second piece of evidence that U.S. foreign policy is shifting relates to current U.S. condemnation of European defense commitments. Trump's focus on European contributions, of course, is not a new phenomenon. Indeed, starting in the 1970s, the burden-sharing debate has vexed the alliance. Every president, including Obama, asked the Europeans to contribute more to their own defense. For instance, Obama explicitly demanded that European partners "step up to the plate and accept responsibility, rather than letting the United States take the strain." While Obama's first Secretary of Defense, Robert Gate, said in June 2011 that NATO risked "collective military irrelevance" unless Europeans bore more of the burden for their own defense.

In fact, the fairness of Europeans not bearing more of the burden resulted in dwindling public support in America-a point that Trump capitalized upon to win support for his election. In 2016, it was clear that not enough Americans appreciated the benefits of leadership on the world stage nor the rules based system that the U.S. established. Trump profited from the U.S. losing patience with its European allies to reverse the decline in their defense spending.

However, what is different from past appeals to the Europeans to do more is Trump's emphasis on the purely quantitative with no consideration of the qualitative aspect of the alliance. Trump's vision does not include the benefits of having allies. Trump said as much in his May 2017 address at NATO Headquarters, where European leaders were visibly shaken. While Trump is plainly a part of a greater trend, he also is visibly escalating the rhetoric in ways that have destructive effects on America's standing and interests on the global stage.

\section{The Return of Realpolitik}

The third sign that U.S. foreign policy is shifting relates to the return of power politics in the world. Realpolitik is back! In addition, it is prompting the reappearance of the sovereign 
state as the most important actor on the world stage. Again, this is something that certainly predates Trump, emerging with Russian adventurism in the east. In this back-to-the-future world, 2014 was a watershed year with such events as Russia seizing Crimea and destabilizing the Donbas region of Ukraine, the shooting down of Malaysia Airlines Flight 17 and the rise of the Islamic State group in the Middle East.

You could argue that these deep structural changes are more important in understanding the transatlantic relationship than the preferences of any sitting president. In fact, that is what the Realists' security seeking explanation of states expects. The point that states want to become less dependent on others looks once again to be exerting centrifugal forces on the process of EU integration and the relevance of alliances, which Realists consistently point out have life-spans. In this line of thinking, the individuals who rise to office are a reflection of that wider context. Meaning, the U.S. Electoral College voted for the Trump administration because he is the best leader to meet the Realpolitik of our age.

If this is true and Realists are right, Europeans must get busy because building a proper defense in the short term will be daunting to impossible. Defense means deterrence and deterrence means an ability to project power, which in turn means a substantial investment in armed forces to the tune of hundreds of billions. In a May 2019 report, the London-based think tank the International Institute for Strategic Studies (IISS) estimated that to defend Eastern Europe without the involvement of the U.S., European NATO members would need to invest up to $\$ 357$ billion and that closing the current military-capability gap would take $15-20$ years.

Thus, the fact that the political unity of the North Atlantic Alliance is being sorely tested over the course of Trump's presidency is problematic for Europe's security and defense. As former NATO Secretary General Anders Fogh Rassmussen recently said in Warsaw, "NATO is militarily strong, but politically weak." Perhaps it is so weak and unpredictable that the EU would prefer another strategic friend amongst the dozens of partnerships that it has brokered in the past decades. Again, a behavior that Realists would predict security seeking states to engage in. Perhaps Trump's questioning of the underlying logic of the alliance will in fact prompt Europeans to contemplate a hedging strategy against possible U.S. disengagement and align themselves instead with an emerging strong state. Perhaps Europeans will hold their noses and form real strategic ties with Russian President Vladimir Putin, who stalwartly stood by his partners in the Middle East. Besides, after Trump's withdrawal of forces from Iraq and Syria, Putin is emerging as the kingpin in the Middle East.

While an alliance with Putin or China is unpalatable, Trump's outright undermining of the unity of the alliance has not gone unnoticed by European leaders. For example, German Chancellor Angela Merkel remarked that Europe can no longer depend on the U.S. and must take destiny in its own hands. Similarly, in an interview with The Economist, French President Emmanuel Macron said that because NATO was experiencing "brain death," Europe should defend itself. 


\section{The Rise of Insurgents}

Now I hope that I made it clear that U.S. foreign policy has shifted and that indeed the question of whether Trump is a symptom or the cause is complex. Perhaps it is more accurate to say that he is both a symptom and a cause. However, what about the U.S. domestic perspective? Why did Americans choose Trump via the Electoral College in 2016? Were they aware of and responding to the trends that I outlined in this lecture?

To answer these questions, I want to tell you a story-one that begins on 5 February 2003. On that day, while I was watching live the Secretary of State, Colin Powel, speaking at the UN, justifying George W. Bush's intention to invade Iraq because of Saddam Hussein's ties to the attackers of the World Trade Center and the Pentagon on September 11, 2001, I got into an argument with my husband, Professor Simon Duke. Simon said that the evidence was ridiculous, that it was made-up, that the reasoning behind Powell's arguments were thin and that the U.S. was committing a grave error. I said, that I believed my Secretary of State, that mobile weapons labs were scary and that if Bush thought the Iraqis were also responsible for 9/11 then riding the Middle East of a known bloody dictator was the right policy.

Of course, it did not take long for Simon to be proved right. In the subsequent admission by the Bush administration that Saddam Hussein had no weapons of mass destruction, as a foreign policy analyst, as an American who felt duped, I wanted to know why Bush led the country to war. My investigation was published in September 2010. ${ }^{1}$ My explanation for the Bush administration's decision to use military force in Iraq found that it was a combination of a highly disciplined neoconservative foreign policy advocacy coalition and Bush's motivations and character that determined policy.

However, the unraveling of this puzzle created more puzzles in its place. Who were these neoconservatives, these Republican foreign policy specialists who used to be Democrats? What made them leave the Democratic Party? When did they leave the Democratic Party? And, how was Senator George McGovern of South Dakota involved in all this?

Now, my story takes an interesting turn, because as many of you know, I am from the great state of South Dakota and I grew up 16 miles away from where George McGovern was born in Avon. If fact, I dare say that he was born in the same hospital as my mom told me every time that we visited the furniture store that replaced it-when she would tell me that she was born upstairs. How could a man born on the second floor of a small-town furniture store in a prairie town with 596 souls, how could this man himself birth a movement that ultimately led America to invade Iraq?

In my research, I found that as a distinct foreign-policy group, neoconservatives emerged in a period of social unrest and political cynicism - a time when insurgent presidential candidates, like McGovern, had profound effects on the outlook and conduct of foreign policy. ${ }^{2}$ I found that McGovern's insurgency was an important historical event that splintered the

\footnotetext{
${ }^{1}$ Roberta N. Haar. 2010.“Explaining George W. Bush's Adoption of the Neoconservative Agenda after 9/11.” Politics \& Policy 38(5) pp. 965-990.

2 Roberta N. Haar. 2017. "Insurgency and American Foreign Policy: The case of George McGovern." World Affairs 180(2) pp. $32-61$.
} 
Democratic Party into disparate foreign-policy groups, including the neoconservatives, who would leave the Democratic Party in the 1970s and by the 1980s find a new home in the Republican Party during the Reagan years. I found that McGovern, and in particular his 1972 nomination as the Democratic Party's presidential candidate, was key to understanding the neoconservatives' disaffection with their own party. I ultimately argued that McGovern's 1972 run for the presidency had a catalyzing and unifying effect on those foreign policy intellectuals who became neoconservatives.

Unexpectedly, while I was thinking about the environmental conditions of McGovern's insurgency in the 1970s during the Vietnam War era, along comes two very clear insurgents in the presidential race of 2016. Suddenly, I saw parallels between the insurgency that tore the Democratic Party apart to what was taking place in the Republican Party. I knew how insurgency affected American Foreign Policy then and later and saw comparable scenarios playing out in 2016. Thus, starting in October 2016, I gave presentations in The Hague, Amsterdam, in Brussels and at various places in Maastricht, all expressing the idea that no matter who won the American presidential election, it would be defined by its rejection of establishment candidates and the electorate's embrace of insurgents, who openly waged war on their own parties. Certainly, Trump secured the Republican nomination by disagreeing with his party's mainstream members on many core issues.

We also know that the Democratic Party had its own insurgent, Vermont Senator Bernie Sanders, who did not win the primary competition but whose popularity, like Trump's, emerged from disagreeing with the traditional Democratic Party on key policy stances. Both Trump and Sanders tapped into the deep discontent felt by a sizable segment of the American electorate. A part of America that felt a loss in its national and personal identity. A part of America that experienced a crisis of confidence in government and leadership. A part of the electorate that saw a government more willing to help refugees, immigrants or the privileged $1 \%$ more than support "Native Citizens." A part of America that experienced a physical insecurity driven by international terrorism and a fear of crime and drugs, which plagued decaying urban and rural communities.

This America embraced Trump and Sanders but not Hillary Clinton, the traditional candidate picked by Democratic Party professionals. My main argument before the 2016 election, based on what I knew about McGovern's effects on the Democratic Party even though he lost, was that if Trump won, U.S. foreign policy would certainly be transformed but even if he lost U.S. foreign policy was likely to undergo significant change. This is because insurgents matter.

\section{A Republican Party Civil War}

Last summer a book came out that was entitled American Carnage (a phrase taken from Trump's inaugural speech). It is written by Tim Alberta, a journalist who wrote for Republican leaning publications. In American Carnage Alberta makes a detailed account of what he calls a "Republican Party Civil War," which started in mid-2016. He interviewed 300 plus people, mostly Republicans, and for me it was gratifying to read that his premise is clearly based on a 
Trump insurgency that was tearing the Republican Party apart. Alberta calls Trump "the unlikeliest of insurgents, the commercial tycoon who cheated the little guy, who employed illegal workers, who made his products overseas, and who enhanced his inherited fortune through scams and fixers and lawsuits, railing against a shredded social contract from the gilded penthouse of his Manhattan skyscraper." Yet, this is the insurgent who captured the White House because some 60 million Americans voted for him, or roughly $25 \%$ of eligible voters. How did he do it?

Trump won the primary race and secured the Republican nomination by opposing Republican Party professionals, in particular foreign policy professionals, over such topics as whether free trade is beneficial for the American economy, whether the U.S. should adopt a more isolationist stance and whether the U.S. should accept more migrants. There were 122 Republican foreign policy experts who signed two different "Never Trump" letters before the election. Peggy Noonan, Reagan's speechwriter, wrote in her Wall Street Journal column that Sarah Palin and Trump represented a "new vulgarization" in American conservatism that embraced grievance and contempt for achievement, which was not good for America.

On 10 October 2016, less than a month away from the election, the Republican Speaker of the House, Paul Ryan, convened a conference call with all 246 House Republicans and told them that Trump was not in keeping with Republican principles and values. Ryan said that he wanted to "un-endorse Trump" in the last month of the election. This did not go over well with some on the call, since some knew that their constituents were dead-set on voting for Trump. These differences were already dividing the party, leading some Republican elites, like Ryan, to argue that Trump engineered a hostile takeover of their party.

These were exactly the same words that those elites who left the Democratic Party in the 1970 s said about McGovern. Thus, I voiced a prediction that the Grand Old Party (GOP) would splinter into groups that supported Trump and those who did not. Some in this audience today scoffed at this prediction when I made it three years ago. However, even if the Republican Party has so far avoided splintering, the Trumpites' revolt will affect the Republican Party and its stance on foreign policy for years to come.

This is because in periods of political cynicism and anti-establishment fervor, insurgent candidates can have profound effects. Already in 1942, V. O. Key described insurgencies as the means by which those disenchanted with the party establishment champion reform. In fact, insurgents emerge because the party's center of gravity is so far removed from the issue preferences of the party's agitators, who want to change the party's positions.

Additionally, in times of political and economic upheaval, the U.S. electorate tends to turn to strong leaders who are outsiders, who are often not politicians or who are not part of the governing elite. At these times, the "doer" characteristic is attractive, with the insurgent being viewed as an action and result oriented person, who is not bound by established precedents, parties or policies. The insurgents are the Radical Reconstructionists, who challenge conventional wisdom, politics and the intellectual establishment-precisely because the party's base is exasperated with "politics as usual." The base wants the insurgent to burn the political house down. 
This is not a new phenomenon, with insurgents emerging in similar circumstances in the past. For example, Pat Buchanan, who ran in 1992 and 1996, ran as a Republican candidate who was unhappy with established policy on immigration. He also wanted to build a wall on the Mexican border. Ross Perot was another insurgent who ran in 1992. Perot said that he would stop the "giant sucking sound" of American jobs going to Mexico. He won $19 \%$ of the vote in 1992 with many claiming that he cost George H. W. Bush a second term with his insurgency. Barry Goldwater was the most substantial insurgent amongst this group. He was the Republican candidate in 1964 and lost by a landslide. Nevertheless, the conservative movement Goldwater sparked influenced the Republican Party for the next 35 years.

On the Democratic Party side, William Jennings Bryan was a prairie populist from Nebraska. He ran in 1896, 1900 and 1908 and was known as "The Great Commoner" because he was critical of banks and U.S. imperialist foreign policy. And then, we have Senator George McGovern, who we already know was also accused of taking over a political party during a presidential campaign - a campaign in which foreign policy was a key divisive issue in the election.

In fact, forty years ago, McGovern, whose primary reason for running for president was his opposition to the Vietnam War, clashed with the foreign policy views of professional Democrats. In 1972, as in 2016, voters across the electoral spectrum expressed a deep-rooted revulsion against big government as well as expressing a distrust of the establishment. In October 1972, the American editor of The Economist wrote, "Mr. McGovern's greatest advantage in the primary campaign was to be running for the Presidency without the backing of Democratic Party officials." In 1972, the leaders of the Democratic Party thought that McGovern's "far-out views on Vietnam" meant that his chances of winning the nomination were "next to zero."

Clearly, the professionals in the party were not paying attention to an electorate that questioned the integrity of establishment officials, with 58\% of Americans stating in 1972 that they thought the U.S. government operated in a manner more beneficial to special interests than to the public. Nor were Democratic bosses paying attention to the agitators in their own party, who wanted a radical transformation of foreign policy-ultimately, at the expense of their party's unity.

I hope by now I have made it clear that insurgents had profound implications for the U.S. in the past. But, there is one further twist in my argument. Can you spot the difference? None of the insurgents that I mentioned except Trump won the presidency, which means in January 2017 we entered unchartered waters on how transformative Trump's insurgency could be.

In the winter of 2016, I started to tell my audiences that like all insurgents, Trump would change Washington more than Washington changes Trump. By May 2017, when retired Republican Speaker of the House John Boehner was asked if the Republican Party could survive Trumpism, he said, "There is no Republican Party. Donald Trump is not a Republican." Boehner said that six months into Trump's presidency, the GOP was an ideology conforming to an individual rather than the other way around. Therefore, today we do not have a Republican 
Party with a man in the White House-we have Trump's Party that happens to be called the Republican Party

\section{What are Europeans to do?}

What does this mean for the U.S., the EU and the world? Although my students know that I am adverse to making predictions or talking about the future, I will venture three scenarios that Europeans might follow in their transatlantic relations. The first scenario is to oppose and delegitimize Trumpian foreign policy and hope that the next president elected in 2020 or 2024 will return the U.S. to the postwar role of maintaining the global liberal order. Those who advocate this pathway, point out that it is not the first turbulent time in U.S. history-just as I noted earlier in this lecture, the U.S. has faced anti-establishment fervor and pendulum swings in politics in its past.

It is also true that America has a history of flirting with populist leaders, who play on fears in their rise to power. For instance, during the Cold War various "Red-baiters," like Joe McCarthy, Richard Nixon, and South Dakota's Senator Karl Mundt, rose to power through stoking fears of communism. Since America survived these past brushes with populism and anti-establishmentism, it has the wherewithal to do so again.

In this line of thinking, Europe needs only to stay true to itself-to stay the course. In fact, Joe Biden articulated this idea when he said at the Munich Security conference in February 2019, "This too shall pass," and "We will be back." The key word from Biden's announcement video (in which he announced that he was running for president) was aberrant. If Trump serves only one term, Biden declared, "I believe history will look back on four years of this president and all he embraces as an aberrant moment in time."

If Biden were to win in 2020, a degree of internationalism might return to U.S. foreign policy, but I am skeptical of that because the other two Democratic candidates that have voiced views on foreign policy, Elizabeth Warren and Bernie Sanders (who happen to also be Biden's key competitors), both see Trump not as a historical aberration but as the outcome of a long historical decline in the U.S.' role on the world stage. This means that Sanders and Warren agree with Trump that U.S. foreign policy needs radical modification. Specifically, Warren and Sanders argue that the strategy of preserving or extending American leadership is "increasingly insolvent."

Moreover, the Democratic Party's new strategic thinkers also argue that Trump is right. These new thinkers, who have become known as the "restrainers," contend in a report published by an important Democratic Party foreign policy think tank (the Centre for a New American Security) that, "To protect what matters most, America should compromise where it matters less, in both Russia's and China's backyards (allow them to have spheres of influence) and hold firm on things like interference in the Western Hemisphere or the developments of WMD that can reach the U.S." This means that the new voices in grand strategy for the Democratic Party are advocating restraint, something that a President Hillary Clinton was sure to find deplorable. It also means that the idea of restraint is becoming mainstream-in opposition to those who espouse U.S. activism on the world stage. Moreover, it means that the 
answer to that question you all have been forming in your minds the last few minutes, whether Trump is still an insurgent-the answer is no. Trump is the new norm.

\section{Work and Ignore around Trump}

So, where does Europe fit into a U.S. strategy of restraint, could European leaders oppose and delegitimize such foreign policies if they had the wherewithal? This brings us to consider the second scenario that Europeans might follow in their future transatlantic relations, a plan that advocates trying to work around and ignore Trumpian policies. In the first year of Trump's presidency, there were some initial signs that this was possible. In fact, Trump's initial cabinet choices clearly picked up where Obama left off in the reinvigoration of NATO. For example, Secretary of Defense James Mattis, assured European allies that the U.S. would adhere to its alliance commitments and that these commitments were in the U.S.' interests.

Additionally, National Security Adviser General H.R. McMaster, with the help of Secretary of State Rex Tillerson, voiced a strong commitment to European allies. Moreover, foreign policy experts in Congress advocated a line of policy that adhered to the postwar consensus, most obviously concerning the maintenance of alliances. For instance, in January 2019, Congress passed a law that prohibits the funding of a U.S. withdrawal from NATO. Moreover, U.S. career civil servants and the majority of Republican foreign and national security experts continue to value transatlantic relations.

Add to this that the Trump administration's official documents, including the National Security Strategy (NSS), the National Defense Strategy (NDS) and the Nuclear Posture Review (NPR), all restate America's understanding of the value of allies and strategic partners, reject isolationism and reaffirm the benefits of America's leadership role overseas. However, it is a worry in this case, that in his remarks announcing the NSS Trump appeared not to know its contents and, perhaps more worrying still, that the authors of the three documents all left the Trump administration by January 2019-a year ago.

The cabinet replacements, such as Secretary of State Mike Pompeo, hold views that are more pessimistic about alliances and transatlantic relations, with Pompeo exhibiting a penchant of knowing how to please his boss, a man who unswervingly remains a NATO skeptic. The obstacles of working around the policies of the largest military and economic power on the planet means that this pathway holds about as much promise as the first.

\section{There Is No Alternative to the U.S.}

The third scenario that Europeans might follow in their transatlantic relations is to acknowledge that Trumpism will determine the course of history while at the same time acknowledging that Europe's security and prosperity still depend on keeping transatlanticism alive, even at some cost.

In the short term, the costs include: 1). a heavy emphasis on economic nationalism, even the weaponizing of the U.S. economy; 2). the downgrading of institutions and international rules; 3 ). the promotion of "sequential bilateralism" and deal-making; 4). the personalization of the diplomatic process; 5). a piecemeal, impulsive and contradictory 
diplomacy; and, 6). the continued erosion of trust across the Atlantic. Along with this, Europeans must accept the short term fact (maybe even long term) that the U.S. no longer wants to play "The City on the Hill" role, thereby shedding a significant source of its soft power, including a rejection of its values-based diplomacy.

\section{Cautious solutions}

These costs will be real to the transatlantic community, which must nevertheless find a path forward. Because finding solutions is still relevant, I will cautiously advance a couple. The first proposal is that Europeans address (with the U.S.) the great-power competition that lies on the horizon, namely that with China. If the transatlantic relationship is to last a long or very long time, it must reinvent itself. Strategic views on China could be the basis of a shared relationship.

For Europeans, aligning future priorities with American interests will be difficult, especially if Trump continues to dismiss the EU as "worse than China." However, in the end, European capitals also need ballast against Chinese pressure and clear assessments of the security implications that Chinese investments in European infrastructure might pose.

The second proposal is to develop (with the U.S.) a common policy towards the Middle East. This is important because the region is still where eight of the world's ten most lethal conflicts are taking place. Moreover, the development of a common Middle East policy could give NATO a new rai-son d'ê.tre, in part, because the European member states are simply geographically closer. Again, this will be hard, given Trump's stance on Iran and his decision to largely withdraw or reallocate military resources from the region.

You may think these proposals are safe and limited. I think so too. And yet, moving forward with them may be impossible. I would like to make one final point today, an echo of a comment made by Clingendael scholar Peter van Ham, that no matter what, Europe's short to medium term future outlook must accept that "There Is No Alternative" (TINA) to the U.S.

That means that Europeans must find a way to deal with the Trumpian new world, because it is here to stay. At least, until the next insurgent comes along.

I have spoken. Ik heb gezegd. 